\title{
What the Metaphor Could Not Tell Us About the Prime Minister's Bicycle Helmet
}

\author{
Rhetorical Criticism of Visual Political Rhetoric
}

\author{
JENS E. KJELDSEN
}

What kind of questions should the academic discipline of rhetoric propose and attempt to answer? If we turn to the rhetorical apparatus, both ancient and modern, and to the history of rhetoric in theory and practice, one central research question emerges: How does one influence people through intentional (i.e. rhetorical) communication? By analyzing a specific discourse, this article tries to both provide suggestions about how the visual rhetoric of this discourse functions and potentially influences people, and to illustrate a general approach to rhetorical criticism. By introducing terms such as latent visual rhetoric and manifest visual rhetoric, and persuasive cues and persuasive hierarchies, the article also seeks to provide some theoretical knowledge about visual rhetoric in general.

One of the most cited texts in works concerning visual rhetoric is undoubtedly The Rhetoric of the Image by Roland Barthes. Along with Barthes' article, Jacques Durand's "Rhétorique et image publicitaire" is considered a seminal article. Both Barthes and Durand represent a French structuralist semiotic tradition. In communication studies, their articles have contributed to a variety of tropological approaches to visual rhetoric. What is common and distinctive to these approaches is that they apply only a very small and limited part of rhetorical theory and its apparatus when explaining visual rhetoric. Critics using insights from Barthes and Durand tend to turn to the ancient rhetorical art of style (elocutio), and especially the art of ornament and adornment (ornatus), one of the four virtues of elocutio. The critic scours pictures for visual elements that might function as a visual trope or figure, and then tries to explain the pictures' visual persuasion through these. The search is mainly for metaphors and metonymies, which as concepts are often paralleled with Roman Jakobson's linguistic concepts of paradigm and syntagm ${ }^{1}$. Thus, the analyses present themselves as a unification of semiotic and structural theory with ornatus. I refer to this method of critique and analysis as the ornatus-approach or the tropological critique of visual rhetoric. Ornatus being only one of the four virtues of elocutio, and elocutio being only one of the five canons of rhetoric ${ }^{2}$, it should be obvious that this approach is only partly rhetorical. ${ }^{3}$

It is necessary here to stress that while Durand truly uses a tropological approach, it would be simplistic to claim that Barthes does the same. Still, it is important to remember that the article "The rhetoric of the image" is more about semiotic signification than rhetorical persuasion. 


\section{Flagraising Studies}

Some explanations of visual rhetoric describe a tropological approach that in fact is little more than the enthusiastic hoisting of a flag every time a trope or figure is located. ${ }^{4}$ Others use the tropes mainly as a means of describing semantic operations, i.e. ways of making meaning, while some try more directly to explain persuasion through these operations. ${ }^{5}$ However different these approaches might be, they all rest on structuralist, instead of rhetorical, ground. They thus share a tendency to overlook important rhetorical knowledge. This knowledge is crucial when attempting to discover how a specific visual discourse works and how it might influence and persuade people. Firstly they tend to disregard the importance of the rhetorical situation. Secondly, they provide a very limited account of the discourse's persuasive elements. Thirdly they overlook the rhetorical strategies and appeals.

Let me now, by way of a specific example, attempt to illustrate some of the problems with tropological critique, and then carry out a more comprehensive rhetorical critique of the same example. Since the endeavor is to show rhetorical limitations of the common critical ground of the different tropological approaches, I will not try to deconstruct an existing analysis, but instead to construct a simple tropological analysis according to the basic structural rules. There is another reason for doing this: Since a critic would never use an example which his theory or analysis could not explain, I have purposely chosen an example of rhetoric that challenges the tropological approach. The example is a political newspaper advertisement from the 1998 Danish election campaign.

In a structural tropological critique of this advertisement, the study would start with the discourse itself (parole), but the endeavor would normally be to reconstruct the language system (langue) behind it. The study would therefore not pay much attention to the specific rhetorical situation. The analysis could look something like this:

The advertisement is a political discourse that aims to persuade the voters to vote for the Social Democratic Party (SDP), presenting a bicycle helmet as a metonymic representation of knowledge (and thereby education). This meaning is created through a relation of contiguity between the helmet and the brain, a representation of space (the inside of the helmet) for content (the brain); a metonymic continens pro contento. When the image is decoded in connection with the written text (see translation below) the advertisement states that we should take care of the system of education, which is metonymically represented by the absent head and brain, which again is metonymically represented by the depicted helmet.

However, we can also categorize the visual message metaphorically: Metaphorically the helmet represents knowledge. This meaning is created through a relationship of similarity between the helmet and the brain, which share the same form. Furthermore, the helmet bears a resemblance to the human skull in both looks and function, and therefore one more relation of similarity can be constructed. Decoding the image in connection with the written text, the advertisement reads that we should take care of the education system, metaphorically represented by the absent head and brain, again metaphorically represented by the depicted manifest helmet. Yet another metaphorical interpretation could spring from the helmet as metaphor for protection: As a bicyclist needs a helmet for protection, the Danish population, or rather you as a citizen, need education to protect yourself.

Such a tropological analysis tells us that there are several roads to the visual creation of meaning. But the fact that the creation of meaning can happen both metaphorically 


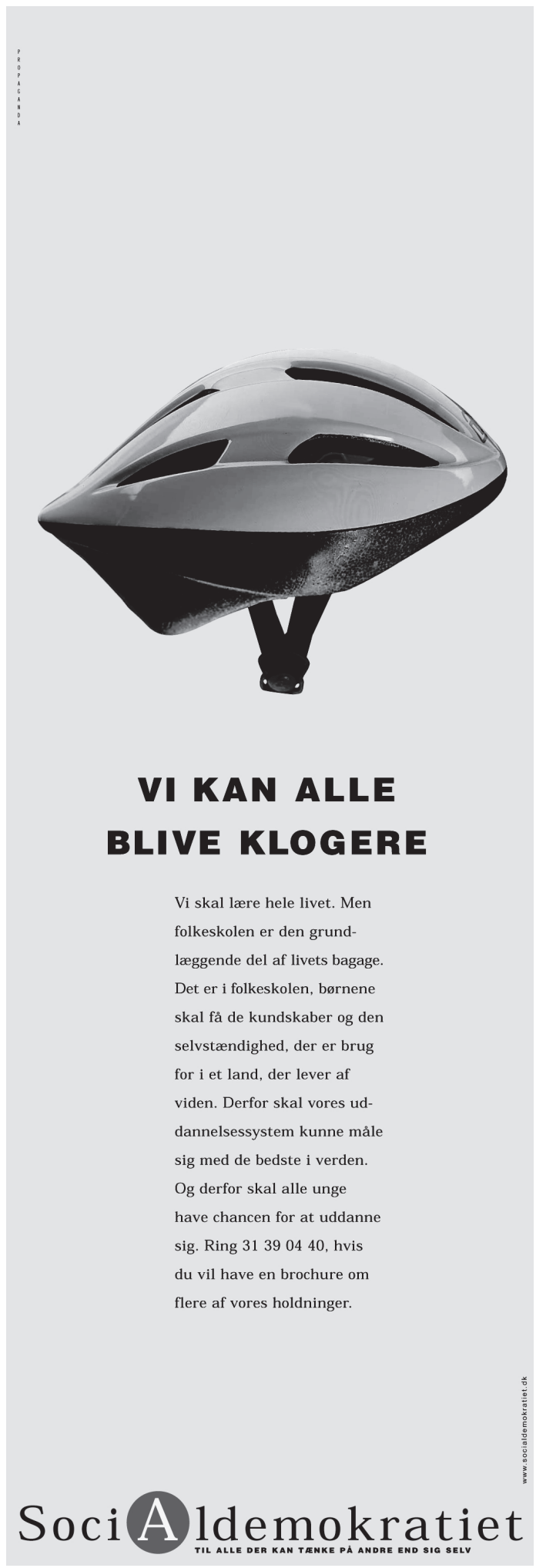

In the 1998 Danish election campaign the advertising agency Propaganda created this advertisement for the Social Democratic Party. The advertisement was published in the Newspaper Politiken Friday, February $27^{\text {th }}$. The size was $52.0 \times 17.5$ centimeters. The headline in the advertisement reads "We can all get wiser", and the text reads: "We shall continue to learn our whole lives. However, the school is the fundamental part of life's luggage. It is in the schools that the children must get the knowledge and the independence, that is needed in a country that lives by knowledge. That is why our system of education must measure up to the best in the world. And that is why all young people must be given the chance to be educated. Call 3139 0440 if you would like to receive a pamphlet on other positions of ours.". The advertisement is reproduced at the courtesy of Propaganda and The Social Democratic Party. 
(paradigmatic) and metonymically (syntagmatic) serves only as a very limited explanation of the rhetorical influence and persuasiveness of both the bicycle helmet and the advertisement as a visual message. This limitation is caused primarily by a lack of situational knowledge.

A Danish reader will know that an important situational element has been left out in the analysis above: The bicycle helmet as a sign of the tainted ethos of Danish Prime Minister Poul Nyrup-Rasmussen (SDP). In 1995, the Prime Minister attracted the nation's attention with his somewhat half-hearted and clumsy participation in a bicycle demonstration against French nuclear testing. Just before he hastily jumped on a borrowed bicycle, someone handed him a bicycle helmet. When the Prime Minister noticed that the helmet was several sizes too small, he received the laconic answer: "Nobody will notice". Not quite nobody. Thanks to a flow of pictures in both press and television and the media's perpetual ridicule, the entire Danish population could not help but noticing. For the opposition, as for many other Danes, the image of the Prime Minister with the little bicycle helmet on top of his head manifested itself as the symbol of his lack of statesmanship and an often artificial and forced staging of political events. The president of the biggest liberal opposition party, Venstre, (The Danish Liberal Party [DLP]) commented on the Prime Minister's bicycle performance this way:

As an elected politician I have at my disposal very different ways of voicing my opinion. So did the Danish Prime Minister. Among other things, he had the possibility to say what he thought about the nuclear tests, when he sat at the dinner table in Cannes during the meeting of the European Council. But there he sat as Mr. Sheepish and said nothing. Instead he jumped on the bicycle. That is not the way a Danish Prime Minister should put forward his views. ${ }^{6}$

While the picture of a bicycle helmet in general can be seen as a sign for both protection and cyclists, in connection with political discourses in Denmark it is a very potent symbol with a specific meaning. Already by taking this specific situation into consideration we are starting to move beyond the structural explanation of langue into a more situational rhetorical and hermeneutic understanding of a specific parole.

As a science that is primarily synchronic and nomothetic, principally seeking the laws of the language system (langue), structural analysis and critique are not designed to take into consideration this single, specific situation wherein rhetoric is are found (parole). ${ }^{7}$ If the specific rhetorical background were applied, how would the analysis then turn out? With the situational rhetorical understanding we can still categorize the helmet as both a metonymic (syntagmatic) relation based on contiguity and a metaphoric (paradigmatic) relation based on similarity. Due to the lack of rhetorical functionality in this distinction, however, we shall not attempt this in detail. Here it will suffice to state that the helmet establishes a connection to the problematic ethos of Prime Minister Nyrup-Rasmussen and his assumed lack of statesmanship. A structuraltropological analysis including the rhetorical understanding of the specific situation would probably describe the message of the advertisement something like this:

As has everybody else, the Prime Minister has made mistakes, and like everybody else he learns from them. Knowledge and education are like a helmet that protects us, and just as it is important for the Prime Minister to learn, it is therefore important for both Denmark and the Danish people that we can learn something all our lives. That is the opinion of The Social Democratic Party, and if you agree you should vote for us. 
However, as any Danish voter would intuitively know, the rhetorical appeal in the advertisement is both something different and something more. This we will look into shortly.

As already admitted, the analysis rendered above is a somewhat simplified version of the semiotic ornatus-approach. It has not been the intention here to vulgarize the tropological analysis, but to make clear its inherent and fundamental ways of thinking and analyzing. It is these basic principles that make the tropological analysis rhetorically problematic, or at least limits its rhetorical field of vision. One rhetorical problem with the tropological analyses and explanations is that a categorization of the visual statement as a metaphor or metonym does not render much substantial rhetorical insight in the way that the advertisement appeals and persuades, or in its rhetorical strategy or presumed effect. Secondly, the structuralist tropological analysis does not normally include the situational circumstances that determine the persuasive value of the statement. This applies to both the specific situation concerning the Danish Prime Minister on a bicycle protesting against French nuclear testing and the many other events that contribute to the creation of the Prime Minister's political ethos.

The tropological analysis can provide us with an understanding of the way we make meaning of a statement. Its main usefulness for rhetorical analysis is this capacity to elucidate the statement and its message. However, this is not enough for a rhetorical analysis. Even when specific rhetorical circumstances are provided, e.g. knowledge of the bicycle helmet's significance-, the tropological analysis still has difficulties in explaining how the advertisement functions rhetorically, how it attempts to persuade, and how this form of persuasion might influence the audience. Furthermore the tropological approach is not designed to make any normative assessments about the rhetorical discourse. Finally, though the structuralist approach might be able to tell us that an understanding of the advertisement can be created through both a metaphoric and a metonymic path, it still cannot provide a very satisfying explanation of how these two roads to understanding may work, or what rhetorical significance it has for the advertisement as a persuasive statement.

\section{Rhetorical Analysis}

By now it should be clear that the proper and most comprehensive understanding of a rhetorical message is to be found neither solely in the structure of the message nor in the langue as a whole. Instead, this understanding should be sought primarily in a specific and limited situation. A rhetorical understanding of the discourse-and thereby of the significance and presumed effect of the appeal-is to be found through an understanding of both the election situation and the specific situation that the bicycle helmet refers to. The combination of a bicycle helmet and the Danish Social Democratic Party evokes the experience of when the Prime Minister wore a too-small helmet. Because his demeanor in the situation in general was considered as unfortunate, or even plain silly or incompetent, the helmet represents this incompetence and silliness. At the same time, the situation is just one of many similar situations. The helmet does not represent only a single event, but a rather certain view of the Prime Minister's ethos. Thus it refers to unfortunate events during his time in office as well as to events in the election campaign that the advertisement was a part of.

In order to understand the rhetorical significance of the advertisement, and to determine the rhetorical significance of its visual elements, we therefore must attempt a more comprehensive rhetorical approach. The approach in the analysis that now fol- 
lows is of course just one of many possibilities. Other rhetorical approaches can be applied depending on the critic's intention and the normative criteria the critic may want to use. Central in the following analysis is an attempt to understand how visual elements work rhetorically, and to reveal which functions they might have in a specific example of visual rhetoric. Rhetoric here refers to a discourse that intends to influence and persuade the audience, and possibly affect the ballot.

Though the account of the rhetorical analysis is carried out step by step, chronologically following the points mentioned below, the actual analysis is not necessarily executed in this way. A rhetorical understanding of the advertisement is only achieved by a continuing rhetorical-hermeneutic alternation between all the elements and the discourse as a whole. The account below is thus arranged chronologically for the sake of illustration and composition. The analysis has four topoi:

I. The Rhetorical Situation

II. The Persuasive elements of the discourse

Location of persuasive cues

Reconstruction of persuasive hierarchies

III. Strategies and forms of appeal in the discourse and the situation

IV. Evaluation of the rhetorical discourse as a whole

\section{The Rhetorical Situation}

Rather than structural explorations of rhetorical 'texts', the comprehension of rhetorical discourses requires an understanding of the rhetorical situation. And an understanding of the rhetorical situation requires an understanding of the necessary components of every rhetorical act and the reciprocal relationship among these components. That is to say the relationship among 1 . Circumstances; 2 . Communicator; 3. Receiver; 4. Medium, genre and form of expression; 5. Message and intention.

The importance of the rhetorical situation is present in the rhetorical tradition from the ancient orators to the rhetorical theorist of today. This includes, sometimes implicitly, the importance of the reciprocal relationship among the necessary components of the rhetorical situation. A rhetorician like Cicero saw such a situational analysis as a departure point for the attempt to create the most persuasive speech ${ }^{8}$. However, this way of analyzing can also contribute to determining whether an effectuated piece of rhetoric might be appropriate and convincing. In its totality, such an analysis involves an account for the relation of each component to the other four components. In total that would mean an examination of ten different relations. However, in our case the purpose of the rhetorical analysis is not primarily a pragmatic and normative determination of how a message should be constructed rhetorically, or if a specific piece of rhetoric is appropriate and convincing. Instead the main purpose is, as already mentioned, to make some substantiated assumptions about how the visual rhetoric in a specific discourse works and influences people. With this purpose the rhetorical situational analysis is still necessary, but it works mainly as a prerequisite rhetorical-hermeneutic analysis of the preconditions for the visual rhetoric.

The Circumstances. The circumstances of the rhetorical discourse in question are the specific events, facts and situations wherein the rhetorical discourse must be seen and understood. For instance, the circumstances that the discourse is a response to. It can 
also be those circumstances which are the necessary conditions or prerequisites for the efficiency and the raison d'être of the utterance. Behind these specific circumstances lie the more general circumstances, such as the time in history and the cultural and social conditions.

As a rhetorical discourse, "The Bicycle Helmet" is a response to the events: election and election campaign. In a time of election, one of the circumstances is the prevalence of two dominating forms of rhetoric: The assessment of the past and the visions and strategies for the future. In the assessment of the past the incumbent government will emphasize all the achievements and positive events during their administration. The opposition, on the other hand, will of course stress the problems and failures of the present government; or if all is well and problems are limited, claim that everything could have been even better if only they had been in power.

In a Danish election campaign, there are traditionally disparities in the quality of campaign material, and a widespread presence of poorly designed material, especially in the case of newspaper advertisements. Traditionally only a few parties use professional communication agencies to arrange their campaign. When a party has members that work as designers or communication consultants, it is common that they will create the campaign material and lay out the campaign strategy. The 1998 election, however, showed an increased use of external communication agencies, and The Social Democratic Party was the first to hire a professional, politically independent advertising agency to oversee their campaign material and campaign strategy.

Among the more specific circumstances in the election campaign was the fact that the government (constituted by the The Social Democratic Party and The Social-Liberals) and the opposition (primarily represented by the The Danish Liberal Party) were strongly opposed. By the time of the election call, the media was already talking about the "presidential election" between Prime Minister Poul Nyrup-Rasmussen (SDP) and the leader of the opposition, Uffe Ellemann-Jensen (DLP). This is noteworthy because Denmark does not have a president, but a Prime Minister, and the Prime Minister is not chosen by the voters, who do not primarily vote for a person, but for a party. Since there are eleven parties to vote for (of which ten are presently represented in the Parliament [Folketinget]), it is a significant sign of the importance and positions of the parties that the media refer to a party election as a presidential election. The term also suggests the rising (media) importance of the two main party leaders (both potential Prime Ministers) and a turn from issue-oriented party politics to image-oriented person politics.

Two other specific circumstances are important: Firstly the fact that the opinion polls, at the beginning of the election campaign, made it clear that the incumbent government did not have enough votes to hold on to power. Thus the government was forced to try to steal votes from the opposition. Secondly, the short duration of the campaign. The election was called February $18^{\text {th }}$ and election day was set to the $11^{\text {th }}$ of May. This gave the parties less than three months to prepare and implement their campaigns, and the last two months before election day were characterized by intense and hectic campaigning.

The Communicator. The communicator in the advertisement is The Social Democratic Party and, implicitly, the leader and Prime Minister Poul Nyrup-Rasmussen. The Social Democratic Party originated from the Danish socialist labor movement and had close links to Marxism, at least until the Second World War. Today - especially after the fall of the Berlin wall - the party has somewhat removed itself from traditional socialism, and moved toward the "Third road" as advocated by Tony Blair and the British 
Labour Party. In spite of this turn toward the Third road, the Labor movement and socialism in many ways still characterize the Social Democratic Party: It still maintains close links to the Labor movement, the $1^{\text {st }}$ of May is still an important day for the Social Democrats, red is still the party's color and the red rose still its symbol. Furthermore, according to the Social Democratic Party's advertising agency, many Danes still conceive the party as a "party of oldish socialist beer bellies with red suspenders, singing Internationale". 9

Poul Nyrup-Rasmussen made his entrance into party politics in 1992 at the expense of then party leader Svend Auken. The change of party leader was marked by conflict. In an article describing the new party leader as a "back stabber", a Danish newspaper named the change "Regicide". ${ }^{10}$ This controversial leader shift was the first in a number of much-discussed events in Nyrup-Rasmussen's political career as party leader-Events that the media described as either unfortunate or plain incompetent. The youth organization of the Danish Liberal Party, for instance, exploited the Prime Minister's tainted ethos in its political campaigning, when it used a daily cartoon to remind the voters of the Prime Minister's blunders (See Cartoon).

In general - and especially during the election campaign - a large part of public opinion conceived of Nyrup-Rasmussen as a staged person, not behaving as himself but rather as a person who willingly gave in to the constraining terms of the media and tried to play the part of a great statesman. In a country where political communication consultants are extremely rare and often viewed with suspicion, there is no wonder that the Prime Minister's extended use of such experts was much discussed. To a considerable extent, his attempted media appeal was perceived as unsuccessful and inappropriate. Already before he became Prime Minister, the media had named him "Mr. Woollyminded talker". During the campaign, the largest Danish newspaper published an article entitled "The Failure of the Consultants. The Danes Turn Away From Dissimulation" "11, which described the impression of the Social Democratic election campaign in this way:

A lot of the voters have - thank God - apparently seen through all the tricks, when a rehearsed and choreographed Prime Minister rushes around the country while he says odd things and has his photograph taken with little children and old ladies.

Intention and message and The receiver. The advertisement's intention was of course to get as many people as possible to vote for The Social Democratic Party, so that the party could stay in government. To do this, the party had to keep the traditional Social Democratic voters and "steal" votes from other parties. As advised by their advertising agency, the Social Democratic Party tried to appeal to young voters and constituents who traditionally vote to the right of the Social Democratic Party. That means, primarily, the Danish Liberal Party and the Conservatives. ${ }^{12}$ To this target group, consisting of many young Liberals, the socialist worldview is bankrupt-it is a worldview without political or personal appeal. To overcome the reluctance and dislikes of these groups of voters, the advertising agency Propganda launched an image campaign attempting to signal a modernized party with a youthful appeal. Thus, both the advertisement and the campaign as a whole aimed to exterminate the view of the party as an out-of-date party for old socialists and blue-collar workers. ${ }^{13}$ The effectiveness of such a rhetorical strategy is challenged by the difficulties in appealing to two different groups at the same time: 1) The voters to the right of the party, recalcitrant to the party's political tradition, 
Jeg spor' mig selv...

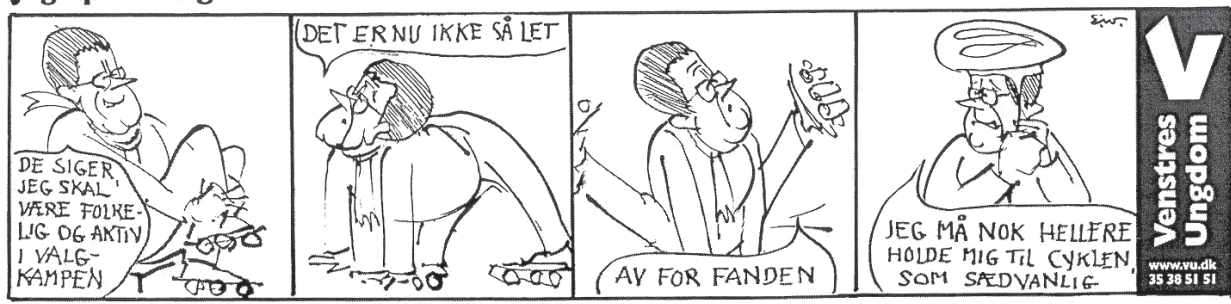

Jeg spor' mig selv...

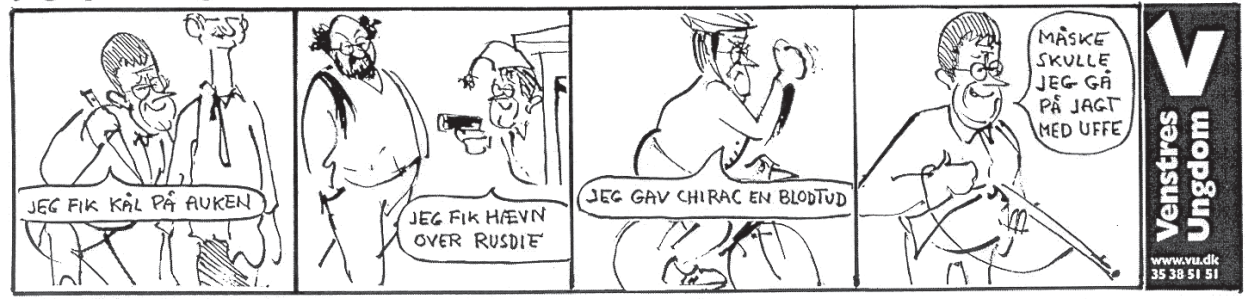

During the 1998 Danish election campaign the youth organization of the Danish Liberal Party presented a daily cartoon in the national newspaper, Politiken. The aim of these cartoons was to remind the voters of the Prime Minister's blunders. Both cartoons are titled "I ask myself...". The first cartoon comments, respectively: 1. the Prime Minister's takeover as leader of the Social Democratic Party from then leader Svend Auken (saying: "I made short work of Auken"); 2. The Prime Minister's anxiety for national safety because fathwa-condemned Salman Rushdie was to receive a literary award in Denmark ("I got revenge over Rushdie"); 3. The Prime Minister's half-hearted participation in a bicycle demonstration against French nuclear testing ("I gave Chirac a bloody nose"). The last frame is a somewhat unclear reference to leader of The Danish Liberal Party, Uffe Ellemann-Jensen ("Maybe I should go hunting with Uffe"). The other cartoon comments on the view of the Prime Minister as a pawn in the hand of the media consultants, presented as a politician who does not mind 'roller-skating' if that would appeal to the media and the public. The advertisements were published in the national newspaper Politiken February $26^{\text {th }}$ and $28^{\text {th }}$, respectively. The size of the cartoons is $10 \times 35$ centimeter. Reproduced at the courtesy of Unge Venstre (The youth organization of the Danish Liberal Party).

and 2) The traditional social democratic voters, recalcitrant to a redefinition of the party, and possibly to the forms of expression chosen to signify this change.

Media, genre and form of expression. The advertisement was part of a campaign from the advertising agency Propaganda. Like the other campaign advertisements, this was inserted in the newspapers with the largest circulation in the country. ${ }^{14}$ Inserted in a newspaper, the advertisement has the communicative disadvantage that the reader might pass it by unnoticed or only read it partly. It is therefore important that the advertisement create attention and interest. On the other hand, a newspaper advertisement has the communicative advantage of using the written form to set forth good and relatively elaborate reasons for the party's viewpoints. This includes giving a proper explanation of proposed policy.

These short remarks on the five necessary components in a communicative act do not qualify as a fully comprehensive, situational analysis. However, they do show the char- 
acter of such an analysis. Hopefully the following will add a further understanding of the value of the rhetorical situational analysis.

\section{Persuasive Elements}

An analysis of visual rhetoric must take into consideration that influencing and persuading can occur in two fundamental ways: As an unconscious, or not thought through, response to persuasive cues, and as a conscious, or thought through, consideration. Social psychologists Richard E. Petty and John T. Cacioppo call these two routes toward persuasion the peripheral and the central routes to attitude change ${ }^{15}$

The central route to attitude change involves the active and conscious deliberation for and against the encountered discourse. The receiver weighs the relevant arguments against each other and determines which side is the more convincing. It is difficult to lead a person through this route, because it requires that the person be involved in cognitive, conscious deliberation. But when a person goes through this central route of attitude change, that change of attitude will be stronger and more persistent. The central route is, of course, especially effective if good arguments are at hand. It is also the most effective route when addressing a recalcitrant audience, because persuading such an audience requires elaborate and detailed argumentation, including refutation. For the same reason, persuading through this route is potentially most easily and efficiently performed in writing.

Deliberations made when going through the central route are primarily rational and can be displayed as persuasive hierarchies of values and attitudes. Such an understanding of argumentation is also dominant in Perelman \& Olbrechts-Tytecas work The New Rhetoric, in which the authors state that orators through their argumentation aim at the "adherence of minds". ${ }^{16}$ Such an adherence, we may add, requires that the speaker find a common ground (topoi, or in the terms of Stephen Toulmin, Warrant) for his message and the receiver.

Basing the argumentation on the common ground that "democracy is desirable" a politician opposed to EU membership can try to persuade an audience that the EU is an undemocratic institution. If members of the audience accept that the EU is undemocratic, they will be influenced (or even persuaded) into casting a "no" vote for membership in the EU. Thus, because a person seeking to persuade must always try to build argumentation on common ground rhetorical, argumentation is always based on hierarchies of values and attitudes. Such hierarchies and persuasive structures can be uncovered, displayed, and analyzed by Stephen Toulmin's model of argumentation ${ }^{17}$, because it makes possible a structuring of the relation between the elements and levels of the argumentation.

In the peripheral route to attitude change the receiver is not actively and consciously engaged. The change of attitude is created not through deliberation, but through so called "persuasive cues." These are "factors or motives inherent in the persuasive setting that are sufficient to produce an initial attitude change without any active thinking about the attributes of the issue or the object under consideration" ${ }^{18}$. These cues-which can be an attractive source or a beautifully designed layout - allow a person to evaluate a communication without engaging in any extensive cognitive work relevant to the issue under consideration. ${ }^{19}$

Because the peripheral route does not engage the person in extensive cognitive work, it is easier to lead a person through this route to attitude change. However, this route does not create a very strong or persistent change of attitude. Because the persuasive 
cues are best at confirming and strengthening present attitudes, this route is especially useful when a communicator does not have substantial arguments and when one addresses an audience favorable to the claim or speaker. For these same reasons the peripheral route is not very efficient in persuading recalcitrant audiences. Finally, due to the transparent character of the persuasive cues, persuading through the peripheral route is potentially more easily and efficiently performed through images.

In the Social Democratic Party's advertisement we find elements that appeal to both the central and the peripheral route. The advertisement uses both persuasive cues and persuasive hierarchies to appeal.

\section{Locating Persuasive Cues}

Three kinds of persuasive cues appear in the graphic design of the advertisement: (1) the use of color, (2) the composition and (3) the individual graphic elements (i.e. the helmet, the text and the logo). Since the advertisement is constructed of very few elements, the use of color is dominated by the plain blue background. On this background, and as a part of the only figurative and photographic element (i.e. the helmet), the bright yellow color dominates. On the bottom of the advertisement, and as part of the word "SociAldemokratiet" ("The SociAl Democratic Party") we find the white 'A' capitalized and enclosed in a red circle. Thus the advertisement has a limited spectrum of colors made up of the clearly distinct colors light blue, yellow and red. To these colors we can add the use of black on the helmet and in the text, and of white in the logo's capital 'A'.

Yellow's tendency of isolation and demarcation is accentuated by the light blue background, and the juxtaposition forms a remarkable and striking contrast. Mentally, the contrast marks confrontation and dynamism rather than harmony and stagnation. In this way the colors express something daring and sprightly, something energetic. Furthermore we normally find these colors and their combination in magazines, commercials and goods aimed at young people. At the end of the 90s, light blue was among the most fashionable colors. Thus the dynamism and energy of the contrast is strengthened by the modern and youthful color choice.

In the specific rhetorical situation, the light blue and yellow primarily connote antisocialism and thus represent a move away from of the traditional Social Democratic Party. ${ }^{20}$ Both colors are almost negations of the red rose and the red banners, and blue is the traditional color of the Liberals. However, the red circle draws in the opposite direction of the blue color's statement of non-socialism and a renewed party. Also, the changed logo, "SocialAldemokratiet" (The SociAl Democratic Party), signifies a changed party - The main change being the introduction of the white ' $A$ ' in capital letters, in the red circle. Since 'A' is the place on the electoral list for the Social Democratic Party, this also serves to emphasize where the voter should place his or her vote (see also note 20). The black part of the bicycle helmet and the black text give weight and tone down the daring and sprightly. This way it is ensured that the bright, distinct and contrastive colors do not render the impression of something rash and uncontrolled.

All things considered, the advertisement's composition has only four visual elements, united in a structure that is simple and austere, with the center as the compositional rallying point. On the light blue background (1), the bicycle helmet (2) floats over the center of the advertisement. Below the helmet, which is surrounded by free space, we find the heading and text (3) united as one visual element. At the bottom of the advertisement, as a foot that provides balance and support, we find the logo 
("SociAldemokratiet") and the slogan (4). The composition has very few visual artistic effects, and few elements at all. It is characterized by simplicity and pronounced lightness. This simplicity and lightness not only makes the advertisement and the advertising concept as a whole recognizable, it is also a persuasive cue indicating the kind of party the Social Democrats have: A dynamic party, one that is not too heavy for change and adjustment to new times.

That the helmet appears to float supports both the compositional indication of lightness and the colors' suggestion of dynamic movement and potential for change. At the same time the very simple, austere composition and black color indicate that the possible change is not an uncontrolled movement, but a controlled act, therefore representing progress rather than confusion. Clarity, simplicity, control and free space (and therefore potential for movement) combined with a restrained use of artistic means can be seen as a sign of quality and competence (as they are often used in commercial advertising). With the simple, controlled and light composition and the sparse use of elements, the composition therefore indicates quality, professionalism and energy.

The advertisement has several graphic elements that function as independent persuasive cues. The short, simple text visually indicates conciseness, energy and honesty. It implies that this communicator does not try to avoid the subject and hide in a political flood of words-this communicator uses no fuzzy or "woolly" sentences or verbal evasions. In contrast to the general view of the Prime Minister as "Mr. Woolly-minded talker", the advertisement seems to signify a political party and Prime Minister that speak out and give plain answers.

Through the use of color, composition and graphic elements, and on the basis of its visual aesthetics, the advertisement creates at least three connected persuasive cuesCues that because of the specific rhetorical situation will be taken as political qualities concerning: 1. Innovation, 2. Energy, dynamism and honesty, and 3. Competence.

\section{Reconstruction of Persuasive Hierarchies}

The rhetorical power of the persuasive cues lies in their transparency; the audience does not notice them or think actively about them. Encountering such a visual discourse, we normally do not consciously reconstruct the immanent persuasive hierarchies of these cues. If we did, we would more readily discover their foundation, and their often insufficient rationality. If we analyze the advertisement's graphic manifestations as argumentation, three main arguments appear, which can efficiently be displayed in the argumentation model of Stephen Toulmin. The italics in the following hierarchies indicate statements that are visually explicit. Anything not in italics is therefore argumentation that is potentially constructed by the reader himself.

\section{First area of political quality: Innovation}

Claim: The Social Democratic Party is not the old unmovable, heavy, socialist labor party it once was, but an innovative, modern and dynamic party.

Data: In the advertisement the party is represented with a new logo, without the red rose and with a modern austere design, dominated by youthful, fashionable and light colors such as yellow and light blue.

Warrant: A change and an innovation in the presentation of political ideas means a change and innovation in political thought. 
Second area of political qualities: Energy, dynamism and honesty

Claim: The Social Democratic Party is an energetic, dynamic and honest party.

Datum A: The party has changed and innovated its presentations and policy (cf. the innovation argument above).

Warrant A: Those who bring change and innovation are energetic and dynamic.

Datum B: In the advertisement the party is visually presented with an austere style and a composition characterized by simplicity and pronounced lightness. Overall the advertisement has few elements, a restrained use of artistic elements and a short text with a limited amount of words.

Warrant B: Simplicity, austerity, few elements, few words and a restrained use of artistic effects are all signs of honesty (and partly also of energy and dynamism).

\section{Third area of political quality: Competence}

Claim: The Social Democratic Party is a competent party.

Datum A: With its limited elements, lightness of design, concise text and controlled use of fashionable colors, the advertisement for the Social Democratic Party presents a professional and dynamic discourse.

Warrant A: It is competent to present a professional and dynamic discourse.

Datum B: The advertisement's design makes it obvious that it has been created by a professional communication agency.

Warrant B: It is competent behavior to use professional communication agencies when dealing in public communication.

In the reception of the persuasive cues of the advertisement, arguments like these will be entangled with each other. The reader that does not go through the central route will thus neither sort out the specific elements of the argument (claim, datum, warrant), nor assess their persuasive relations. The reader will instead meet a clustering of persuasive cues, i.e. one undifferentiated statement indicating that the Social Democratic Party is an innovative, contemporary, professional, energetic and dynamic party (or at least that it wants to present itself as such).

While it is true in some cases that the way one behaves and presents oneself discloses something about how one actually is and what one thinks, the argument in this case is not as straightforward. First, here it is not the Social Democratic Party that expresses itself, but an advertising agency expressing ideas for the party. Does this still include the assumed link between form and content? Is a party really professional, just because it uses competent professionals? Regardless of the answers to questions like these, the rhetorical importance of persuasive cues is that their reception does not normally include analytic thinking like this. They instead render an uncontested view of the communicator through the form of the message.

Even more interesting in the construction of persuasive hierarchies is the choice of the bicycle helmet as a visual symbol. For the members of the audience who do not contemplate the meaning of the helmet, it will function as a persuasive cue about the qualities safety and protection, and about a problematic ethos. These qualities cannot as a matter of course be meaningfully connected, and they have no direct connection with the design and graphic of the advertisement, or the heading "We can all wise up". This 
lack of connection and obvious meaning forces the audience to contemplate the meaning of the bicycle helmet and the advertisement as a whole. In this way the audience is forced to cognitively go through the central route to attitude change. The persuasive implications of the use of the helmet can be illustrated in the following manner:

\section{The bicycle helmet argument}

Claim 1. You should vote for Prime Minister Nyrup-Rasmussen (i.e. The Social Democratic Party), because he has political qualities.

Datum 1: Prime Minister Nyrup-Rasmusen has humor, self-irony, and self-insight.

Warrant 1: It is sensible to vote for candidates with political qualities, and humor, selfirony, and self-insight are political qualities.

\section{Claim 2/}

Datum 1: Prime Minister Nyrup-Rasmussen has humor, self-irony, and self-insight.

Datum 2: Prime Minister Nyrup-Rasmussen admits and points out his own blunders.

Warrant 2: A person that admits and points out his own blunders has humor, self-irony, and self-insight.

Claim 3/

Datum 2: Prime Minister Nyrup-Rasmussen admits and displays his own blunders publicly.

Datum 3: Prime Minister Nyrup-Rasmussen presents the visual symbol for his blunders (the bicycle helmet) in his own advertising.

Warrant 3: To present the symbol of your blunders in your own advertising is publicly admitting and displaying your blunders.

At this point our rhetorical analysis differs from the tropological in several ways. Instead of beginning with and placing emphasis on the discourse in order to reconstruct a hidden langue, the rhetorical analysis begins with and emphasizes the rhetorical situation. Then, in the light of the situational analysis, the rhetorical critic looks for persuasive elements in the specific discourse (parole). Locating the persuasive cues is in many ways similar to the tropological analysis, but is more directly oriented toward persuasion, and is not tightly connected to the verbally anchored apparatus of ornatus. Furthermore, the locating of persuasive cues is just one step on the rhetorical analytical road. The ability to locate is pre-conditioned by the situational analysis and is elaborated in the reconstruction of persuasive hierarchies. Then (as will be shown shortly) the cues will be used in exploring the rhetorical strategies and forms of appeal.

The reconstruction of persuasive hierarchies is not used in tropological analysis, but is important for rhetorical analysis. Such an ordering and display of the arguments can clearly illustrate how the elements are related. Furthermore it reveals the ground on which the argumentation is built. Warrant 1 , for example, clearly reveals that the argument's foundation is the conception that humor, self-irony and self-insight are political qualities. Understanding this is a prerequisite for an assessment of the visual argumentation. The reconstruction also clearly tells us that only a very limited part of the argumentation is explicit (the arguments marked by italics), and that it is not (main) claims, but the data that are explicit. Thus the audience itself must create the argument and make explicit the claim, thereby participating in its own swaying. 
For our purposes, the display of the hierarchies was primarily meant to illustrate the usefulness of Toulmin's argumentation model as an analytical means. Using all of the model's elements and terminology, and analyzing the structures, elements, and fundament in more detail, the rhetorical analysis could be made even more precise and comprehensive.

\title{
III. Strategy and Appeals
}

It now begins to be clear that the main visual strategy (or mode of operation) is dominated by two appeals to ethos. One is the use of persuasive cues in the graphic visual design that presents the Social Democratic Party in a professional, dynamic and competent way. This appeal aims at image building and persuading the audience that the party is competent and contemporary. The other appeal to ethos is the use of the helmet as evidence of the 'political' qualities (humor, self-irony and self-insight) of the party leader and hence the party in general.

Both the overall graphic design and the helmet as a visual symbol appeal to good moral character (aretè) ${ }^{21}$. The primary visual appeal is thus to ethos, and both the general design and the irony are forms of enforcement of political image. The visual uses ethos to appeal to an appreciation of self-irony and thereby attempts to create a change of image for the Social Democratic Party. The verbal primarily uses logos in an appeal for the importance of education, and thereby implies that you should vote for this party because it appreciates the importance of education. The crucial question here is the visual appeal, and therefore we shall not concern ourselves particularly with the verbal appeal. However, it is notable that the written text presents nothing but generalities, commonplaces, and empty remarks. The title is "We can all get wiser", and the text reads as follows:

\begin{abstract}
We shall continue to learn our whole lives. However, the school is the fundamental part of life's luggage. It is in the schools that the children must get the knowledge and the independence, that is needed in a country that lives by knowledge. That is why our system of education must measure up to the best in the world. And that is why all young people must be given the chance to be educated. Call 31390440 if you would like to receive a pamphlet on other positions of ours.
\end{abstract}

Every single statement in the text could out of hand be placed in any Danish party's advertisement. The text says nothing but states that education is important-a political commonplace that no one will disagree in.

Through these considerations we can, among other things, establish that the advertisement employs different appeals in the verbal and visual statements. It employs a verbal appeal to logos characterized by political generalities, and a visual appeal to ethos characterized by the (re)construction of image. Knowing the character of these appeals is important in determining the rhetorical significance of the visual, and the assessment of the rhetorical, discourse.

\section{The Rhetorical Significance of the Visual}

The visual is significant in its ability to attract attention and create interest. The austere visual design and sparse text are a promise to the reader that here is a statement that does not require too much cognitive energy. This promise of limited labor in decoding invites the reader to a closer look at the advertisement's message. Furthermore, the 
mysterious combination of the bicycle helmet and the heading: "We can all get wiser" both creates attention and holds the reader's interest. The visual composition thus has the same function as the exordium in the traditional rhetorical speech: To create attention and interest, and to win the good will of the audience (captatio benevolentia).

When interest has been created, the reader encounters the "real" visual rhetoric. Here we can distinguish between two main forms (strategies): The latent and the manifest.

\section{Latent Visual Rhetoric}

Latent visual rhetoric is characterized by the fact that it does not obviously present itself as rhetoric and is not at first thought of as rhetoric. It therefore leads the audience through the peripheral route. The function and persuasive value of this type of visual rhetoric is primarily to hide that it is rhetoric. Though the latent visual rhetoric creates claims and arguments, it is rhetorically important that they are not perceived as claims and arguments. It is precisely characteristic for persuasive cues that they are seldom consciously perceived as claims or arguments.

In our specific advertisement, the persuasive cues give mainly an impression of the kind of party the Social Democratic Party is (or wants to be regarded as). However, though the visual representations exert rhetoric in this way, they do not appear as statements or arguments, and therefore evade the cognitive engagement of the reader. The rhetorical advantage of visually showing the statement about the Social Democratic Party is that it in this way is not claimed, but just appears, and therefore just 'is'. To let something appear without spelling it out explicitly, is especially important in mediation of ethos and image. Both common knowledge and rhetorical theory ${ }^{22}$ tell us that we do not improve our credibility just by saying that we are professional, dynamic and contemporary, but by behaving professionally, dynamically, and contemporarily. Through the visual, one can represent statements that would seem importunate if expressed verbally and explicitly.

Of course, it is possible to appear professional, dynamic, and contemporary through a written text, without explicitly claiming to possess these qualities. However, the visual representation can deliver this message faster, more effectively, and more economically than the verbal. This is very important because readers normally do not deploy much time, attention, or cognitive energy into advertisements. In contrast to the cognitive labor it takes to engage in and read a text, all we must do with a visual advertisement like this one is glance at it to understand the message about the Social Democratic Party's image.

The visual rhetoric, which apparently shows the content of the message to the eye, seems to make it invisible to conscious thought. The visual argument is not perceived as an argument, because the argument is not perceived. By contrast, the verbally expressed argument does not make its content visible to the eye, but restricts itself to tell it, using the arbitrary connection to the written text. It is precisely through this verbal invisibility that the content of the argument makes itself seen to the mind of the audience. One can almost say that we realize what is written but do not see what is shown.

\section{Manifest Visual Rhetoric}

Manifest visual rhetoric is characterized by the fact that the visual representation obviously functions as rhetoric. This primarily leads the audience along the central route to attitude change. The function and value of this type of rhetoric is first and foremost to 
make audience members engage in construction of persuasive hierarchies and consider consciously certain arguments.

In the specific advertisement, the main entrance to the central route to persuasion is through the use of the bicycle helmet as a symbol. Since it is obvious that the helmet functions as a statement in a persuasive context, the reader will almost inevitably assess what the helmet is used to state. Thus the reader engages himself in a cognitive deliberation. Through the wish to understand and create meaning, the reader is forced to consider the topic that the visual representation brings forward: the ethos of Prime Minister Nyrup-Rasmussen. The use of such visual representations and symbols to lead the audience into persuasive hierarchies is rhetorically advantageous because these representations do not directly seem to claim anything, but instead just indicate arguments. In so doing they create what we can call controlled freedom in the construction of persuasive hierarchies. The reader knows that the helmet is part of a political and rhetorical context, and will therefore-either intuitively or consciously-try to construct a persuasive argument that gives meaning rhetorically. As the communicator is the Social Democratic Party, the meaning cannot be the claim that the Prime Minister is a staged, incompetent, bicycle riding politician. In the search of rhetorical coherence and meaning, the reader is led to the construction of the argument about the political qualities of the Prime Minister. In this way the bicycle helmet functions as a visual enthymeme.

In his reinterpretation of the Aristotelian enthymeme, Lloyd F. Bitzer has advocated that the essence of the enthymeme is that it is constructed by speaker and audience in communion. In the enthymemes of a speech, the premises are omitted, so that audience members must contribute the premises themselves. Thus, the members of the audience themselves help in creating and completing the syllogistic argumentation by which they are persuaded. Thus, according to Bitzer, the enthymeme holds an important persuasive value in its ability to help create a self-convincing audience. Self-convincing is a most effective form of convincing, because the person is actively engaged in creating the arguments himself. Seemingly, audiences are offered the freedom to draw their own conclusions, and they think that they themselves have worked out the answer. This is exactly what the advertisement attempts to accomplish.

In this explanation of the advertisement's rhetorical function it is important to remember that the visual enthymeme created by the image of the bicycle helmet is just a part of a more comprehensive rhetorical discourse: the advertisement as a whole. What determines the rhetorical value of the image is its relation to this context. The closest and most important relation is to the heading and text under the picture. Therefore a few remarks about this are necessary.

\section{Anchorage and Relay Rhetorically}

In a great deal of rhetoric the visual and verbal messages are used to strengthen and support each other. This support can occur because both discourses redundantly express the same thing, and thereby emphasize similarities in meaning (anchorage), or it can occur because the visual and the verbal express something different, emphasizing differences between the two discourses (relay), thereby creating a new 'statement' of a higher $\operatorname{order}^{23}$. The operations anchorage and relay create meaning, but not necessarily rhetoric-Which does of course not mean that these operations are not rhetorically relevant, just not rhetorical in themselves.

In our specific case anchorage does not occur. However, it could be argued that the visual statement about the ethos of the Prime Minister and the Social Democratic Party, 
along with the verbally expressed statement about educational policies, create an interplay between signifier and signified, and therefore the verbal and the visual are united in a statement of a higher order. However, because differences in meaning can only be seen on the background of existing similarities, anchorage is a necessity for the function of relay, and thus for the creation of a meaning of a higher order. Because the image of the helmet as a visual symbol possesses so many different and distracting meanings, this anchorage does not occur.

There is not a clear enough connection between the references to the events connected to the bicycle demonstration against French nuclear testing and educational policies to form a united message. In the end, both modes of expression act on their own behalf. The advertisement does not hold the redundant, reiterating power of anchorage nor the communion of two different modes of expression in a third message. The visual rhetoric does not seem to be maximally utilized.

\section{Assessment of the Rhetorical Discourse as a Whole}

The conflict between the statement of the advertisement and the reader's perception of the real events.

Displayed in formal persuasive hierarchies, both the appeal to logos and the ethos are logically valid. While the validity of the arguments can hardly be questioned, the truth of their premises, or their degree of their probability can. We can, for instance, question whether it actually is the Social Democratic Party that expresses itself in the advertisement, and we can question the 'value' of the argument when recognizing that it is not the Social Democratic Party but the advertising agency expressing the arguments. Also, the implicit argument about the Prime Minister's ethos is logically valid. It is not very debatable that the advertisement actually represents and admits the blunder(s) of the Prime Minister. And it is hardly debatable that representing and admitting your own blunders is normally a sign of humor, self-irony, and self-insight. The argument about humor, self-irony and self-insight is therefore in a sense self-fulfilling, because the blunder is actually presented.

However, this does not mean that the argument was convincing. The claim was in conflict with the view held by a considerable part of the public. Generally, and in the election campaign especially, the public did not conceive of the Prime Minister as a straight-talking person with the 'political' qualities of humor, self-irony and self-insight. He was, as we have seen, rather perceived as a 'woollyminded talker' and a staged person not behaving like himself, but instead trying to please the media, playing the role of the great statesman. Since the attempt at the role of great statesman-as described earlier- was generally perceived as a failure, it concurred with neither the assertions of competence nor those about humor, self-irony and self-insight.

The discrepancy between the view of the Prime Minister's political appearance and the advertisement's assertion erodes the entire message of the advertisement. That the advertisement is paid for and created by an advertising agency even conveys the risk that the whole advertisement is considered a part of the staging of the Prime Minister. If this happens, the advertisement will deconstruct its own persuasion, and refute itself.

Ambiguity and double communication. As are many of the other advertisements created by Propaganda for the Social Democratic Party, "The Bicycle Helmet" is a visually ambiguous discourse. On one hand such an ambiguity is a rhetorical advantage, because it creates attention and engages the reader cognitively in determining the meaning of the message. On the other hand the ambiguity is rhetorically problematic, because the 
many possible decodings and interpretations of the advertisement are left without much interpretative control.

In "The Bicycle Helmet" the value of the ambiguity is diminished because the ambiguity is too open and uncontrolled. Firstly, this is caused by the ambiguity of the helmet's role as a symbol, and secondly due to the lack of anchorage between the different modes of expression. Encountering the picture of the helmet and the text "We can all get wiser", the reader will presume that the picture refers to the Prime Minister and that the text does too-That is not the case. The text is about how important education is, and how important it is to gain knowledge throughout life. Because the helmet as a symbol is dominated by connotations about the Prime Minister's ethos, the connection between bicycle helmet and education is recalcitrant. The advertisement sends a confusing and thereby unrhetorical message. Consequently, the power of the central route to persuasion is undermined, and the readers largely left with the persuasive cues leading to the peripheral route.

Furthermore, when using images it is communicatively hazardous and possibly inappropriate to simultaneously talk seriously about the importance of education and try to be humorous and self-ironic. It is easier to be both serious and funny or self-ironic during a speech. Due to the linear and temporal communication form of a speech, it is by nature possible to alternate between styles. Without losing the confidence of the television audience, a news reporter can first, with a concerned expression, announce death and suffering following a natural disaster, and then turn his face into a smile announcing that a Panda in a Chinese zoo just had twins. Because non-moving images do not unfold in time as moving images do, such changing of styles is extremely difficult when communicating with images. When trying to appeal through both a serious and a funny style within the same image, it is likely that the discourse will be conceived as announcing a natural disaster with a smile.

Image and recalcitrant audience. The primary function of the visual in the present advertisement can be determined as an attempt at an appeal to ethos in order to create a change in image. In the specific rhetorical situation, this strategy is problematic. To change and consolidate an image takes time and can hardly be achieved in an election campaign as short as the 1998 Danish campaign. Image campaigning requires continuous marketing during a substantial period of time.

Add to this that it is probably more difficult to succeed with image campaigning in politics than in the pure commercial realm. In Scandinavia this is partly because parties simply cannot afford the price an image campaign of long duration would have. Secondly, it is difficult to succeed with paid image campaigning in Scandinavia because the construction of a party's (and a politician's) image is created primarily by the daily nonpaid appearance of the politicians in the media. ${ }^{24}$ In their day-to-day work politicians are effectuating ongoing image campaigns for themselves and their parties, and the effects of these campaigns are much stronger and more lasting than the effects a short paid campaign before an election can produce. Moreover, the message of image campaigning seems unreliable when this campaigning only appears just before elections.

The analysis of the advertisement "The Bicycle Helmet" indicates that in some cases in politics-and I believe in most cases-the best ethos is created through the logos of the politician. The image of the politicians and the parties first and foremost depends on how they act politically. Mostly, the content determines the form, and not the other way around. For the same reasons I do not consider it likely that Scandinavian election campaigns can primarily be won through image campaigning. 
In "The Bicycle Helmet" the image changing appeal is primarily created through visual persuasive cues. As mentioned earlier, such persuasive cues do not entail an effective way of persuading engaged readers in affairs that have personal relevance and/or might have personal consequences. ${ }^{25}$ In a Scandinavian election campaign, where voter turnout is normally between $70-90 \%$, the voter will almost always have some form of conscious involvement in the election and experience some kind of personal relevance toward it.

Under normal circumstances it is likely that the average voter in a Danish election campaign is so involved in the campaign that he or she will choose the central route to attitude change. If met by discourses that mainly appeal through persuasive cues, by the previous account this voter will probably reject it. This is especially true for the Social Democratic Party advertisement, because both the advertisement and the election campaign as a whole are directed toward voters who do not traditionally vote for the Social Democratic Party, and therefore can be expected to be not only concerned about the election and politics in general, but also recalcitrant. Recalcitrant and concerned voters are not swayed by persuasive cues. To move voters from one party to another requires more than a contemporary and dynamic design. This 'more', could have been the statements in the written text, but here the voters are served generalities and political commonplaces-Empty political statements so general that they only work as persuasive cues.

Hopefully the analysis of "The Bicycle Helmet" has illustrated that when we try to understand how rhetoric works and potentially influences people, we must consider the rhetorical situation, the persuasive elements and the rhetorical strategies and forms of appeal. The tropological analysis does not entail such considerations because it originates from structuralist semiotics, which is not a theory about persuasion or argumentation but about meaning and how meaning is created. This means that it has neither a method nor a system of terminology that can deal with persuasive hierarchies of values and attitudes or general rhetorical strategies and appeals. The tropological analysis cannot in an analytically expedient way distinguish between a simple statement and an argument, or determine whether something is a good or a bad argument-be it in ethically or efficiently good or bad.

Of course, this does not mean that the tropological analysis is useless-Far from it. Structuralist insight and some forms of tropological analyses can be very helpful in decoding and determining the meaning of specific rhetorical discourses. Still, the structuralist or tropological approach does not qualify as primarily rhetorical. Because rhetorical discourse is fundamentally situational, a search for a hidden rhetorical langue that can account for the persuasiveness of all rhetorical utterances ${ }^{26}$ is bound to be in vain. Before Monica Lewinsky, one could seriously state that "Bill Clinton is truly a considerate father". When ironically stating the same words today, nothing in the structure of the sentence has changed; The new rhetorical quality of the statement stems solely from the new situation and the ironical intention. In other words, the rhetorical is not primarily to be found in the structure of the signifier, but in the situation wherein the signifier is embedded.

Besides illustrating a more comprehensive and situational rhetorical analysis, the critique of "The Bicycle Helmet" has hopefully also produced some insight into how intentional visual communication possibly influences people, as well as presented the value of the rhetorical analysis. In general we can say that the overall objective of the tropological analysis is non-evaluating and semantic or semiotic; while the overall ob- 
jective of the rhetorical analysis is evaluative and pragmatic or functional. The first describes how meaning is created in general, the second how specific instances of rhetoric work and how they can be judged.

\section{Notes}

1. The fusion of the of the concepts paradigm/syntagm with the concepts metaphor/metonymy happens with Jakobson (1956). For comments and accounts of this fusion see Barthes (1980, page 50, including note 2), and Vickers (1997, pages 442-53). Gérard Genette (1970) writes about tropological reduction, referring to the gradual limitation first from a general rhetoric to the treatment of rhetorical tropes and figures, and second to only metaphor and metonymy, then finally exclusively to the metaphor. With reference to Groupe $\mu$ (1970), he says: "Nowadays we call general rhetoric what is in fact a treatise on figures" (page 103f).

2. The five canons (alternatively called the parts, faculties, functions, categories, or divisions) represent the five fundamental rhetorical issues: Inventio (Invention), Dispositio (arrangement, organization), Elocutio (Style and adornment), Memoria (memory) and Actio (delivery and presentation). The four virtues in Elocutio are Perspecuitas (clarity), Decorum (aptness), Puritas (Correctness) and of course Ornatus (adornment).

3. For a more elaborate theoretical treatment of the limited rhetorical foundation of the ornatus-approach see Kjeldsen (1999).

4. See for instance Bonsiepe (1961), Durand (1987), Dyer (1990) or Walker \& Chaplin (1997: 119ff). Dyer has one of the most thorough applications of the tropological critique. A whole chapter, "The Rhetoric of Advertising", is based on Roland Barthes' "The Rhetoric of the Image" and Jacques Durand's "Rhétorique et image publicitaire".

5. Larsen (1980), Paine (1981), Durand (1987), Heradstveit \& Bjørgo (1987), Fiske (1990), Skretting (1995), von Der Lippe (1995), Nordström (1986), page 119ff, (1996). In continuation of (and partly in opposition to) Jakobson, Barthes and Durand we find Umberto Eco's treatment of "The Rhetorical Labor" in A Theory of Semiotics (1979) and Johansens "Semiotics of Rhetoric: The Consumption of Fantasy" (1989).

6. Matz 1998, Page 21. The comment originally appeared in the newspaper B.T. 1995.

7. In the structural tradition of Ferdinand de Saussure, who mentions in his Course in General Linguistics (1959: 16) that linguists study langue, which has two aspects: The synchronic (the system at a given time) and the diachronic (the history of the system).

8. Cicero writes in De Oratore III.liv.210 : "no single kind of oratory suits every cause or audience or speaker or occasion" (my italics) and hereby both mentions the necessary components of every speech act and underscores the value of a situational analysis.

9. Interview with Frederik Preisler from the advertising agency Propaganda (September 8, 1998).

10. The article "The Rose is in Poisoned Water. The Regicide, the Character Assassination, the Coup" ("Rosen står i forgiftet vand. Kongemordet, karaktermordet, kuppet") was published in the newspaper Berlingske Tidende on March 22nd, 1992. The article describes an extraordinary executive committee meeting in the Social Democratic Party, where a prominent party member and former minister (Mogens Lykketoft) proposed Poul Nyrup-Rasmussen as the party candidate for Prime Minister instead of then party leader Svend Auken.

11. Ekstra Bladet Thursday, March 5th, 1998.

12. Interview with Frederik Preisler from the advertising agency Propaganda (September 8, 1998).

13. Interview with Frederik Preisler from the advertising agency Propaganda (September 8, 1998), cf. note 9.

14. On Friday, February 27 th, it was inserted on a half page in the broadsheet format of Politiken (Size $17.3 \mathrm{x}$ 21.2). The same day it was inserted on a full page in the tabloid format of Ekstra Bladet. The elements were the same, but the advertisement had a somewhat different composition.

15. Petty \& Cacippo (1986).

16. Perelman \& Olbrechts-Tytecas (1971), page 14.

17. Toulmin (1994), Toulmin, Rike \& Janik (1978).

18. Petty \& Cacioppo (1986), page 256.

19. Petty \& Cacioppo (1986), page 256.

20. For the same reasons the advertising agency for the Social Democratic Party (Propaganda) advocated that the circle with the capital A - seen in all of the campaign material for the Social democrats - should be in yellow. The Social Democratic Party considered the proposal to be radical, and rejected it in fear of frightening off traditional social democratic voters. It was put forward by party members that yellow was a 
strong "non-social democratic" signal, and that yellow is the color of deceit (Interview with Frederik Preisler from the advertising agency Propaganda the 8th of September 1998).

21. Following Aristotle's distinction between good sense (Phronesis), good moral character (arete) and goodwill (eunoia) in book two of the Rhetoric.

22. See for instance chapter VI ("Making Discourse Ethical", especially page 191) in Garver (1994), which describes how the best ethos is created through the good logos.

23. Barthes (1977), Larsen (1995), page 27. In exemplifying relay, Roland Barthes refers to cartoons: "The function of relay is less common (at least as far as the fixed image is concerned); it can be seen particularly in cartoons and comic strips. Here text (most often a snatch of dialogue) and image stand in an complementary relationship; the words, in the same way as the images, are fragments of a more general syntagm and the unity of the message is realized at a higher level, that of the story, the anecdote, the diegesis" (1977) page 41.

24. In Denmark the political candidates participate in television debates, political interviews and other programs much more than candidates in, for instance, the U.S.-and are seen and heard by a large part of the population (See for instance Kaid \& Holtz-Bacha 1995). Another important difference between political campaigning in Scandinavia and the U.S. is that, except for Finland, political advertising on television is prohibited in all of the Nordic countries (Sweden, Denmark, Norway and Iceland).

25. Petty \& Cacioppo (1981), (1986) page 81-5, (1996) page 258-90.

26. As Roland Barthes seems to suggest in "The Rhetoric of the Image" when he writes: "Classical rhetoric needs to be rethought in structural terms (this is the object of a work in progress); it will then perhaps be possible to establish a general rhetoric or linguistics of the signifiers of connotation, valid for articulated sound, image, gesture, etc." (1977) page 50. The "work in progress" was later published in Communications 16, (1970) as "L'ancienne Rhétorique (Aide-mémoire)"; the structural approach is further elaborated in the general theory of the figures of language as proposed by Groupe $\mu$ (1970).

\section{References}

Barthes, Roland (1977 [1964]) Rhetoric of the Image. In Barthes, Roland: Image, Music, Text. Essays selected and translated by Stephen Heath. New York: Hill and Wang, pp. 33-51.

Bitzer, Lloyd F. (1959) Aristotle's Enthymeme Revisited. Quarterly Journal of Speech, vol 45, pp. 399-408.

Bonsiepe, Gui (1961) Persuasive Communication: Towards a Visual Rhetoric, Uppercase 5, London: Whitefriars Press, pp. 19-34.

Durand, Jacques (1970) Rhétorique et image publicitaire, Communications 15, Paris: Centre d'etudes des Communications de masse. Ecole Pratique des Hautes Etude, pp. 70-95.

Durand, Jacques (1987) Rhetorical figures in the Advertising Image. In Umiker-Sebeok, Jean (ed.) Marketing and Semiotics, Berlin, New York, Amsterdam: Mouton de Gruyter, pp. 295-318.

Dyer, Gillian (1990 [1982]) Advertising as Communication. London: Routledge.

Eco, Umberto (1979 [1975]) A Theory of Semiotics. Bloomington: Indiana University Press.

Fiske, John (1990 [1982]) Introduction to Communication Studies. London: Routledge, $2^{\text {nd }}$ edition.

Garver, Eugene (1994) Aristotle's Rhetoric. An Art of Character. Chicago, London: The University of Chicago Press.

Genette, Gérard (1970) Rhetoric Restrained. In Figures of Literary Discourse. Columbia University Press, pp. 103-126. (Originally: La rhétorique restreinte, Communication 16, Paris 1970)

Groupe $\mu$ (J.Dubois, F. Edeline, J-M. Klinkenberg, P. Minguet, F. Pire \& H. Trinon) (1970) Rhétorique générale. Paris: Larousse.

Heradstveit, Daniel \& Tore Bjørgo (1987) Politisk kommunikasjon. Introduksjon til semiotikk og retorikk. Oslo: Tano A.S.

Jakobson, Roman (1956) Two Aspects of Language and Two Types of Aphasic Disturbances. In (ed.) Halle, Morris \& Jakobson, Roman (eds.): Fundamentals of language. The Hague: Mouton.

Johansen, Jørgen Dines (1989) Semiotics of Rhetoric: The Consumption of Fantasy. In Sebeok, Thomas A., (ed.) Umiker-Sebeok, Jean. The Semiotic Web. Berlin/New York: Mouton de Gruyter, pp. 301-332.

Kaid, Lynda Lee \& Christina Holtz-Bacha (1995) Political Advertising in Western Democracies: Parties and Candidates on Television. Thousand Oaks, CA: Sage Publications.

Kjeldsen, Jens Elmelund (1999) Visual Rhetoric - From Elocutio to Inventio. In Blair, J. Anthony, van Eemeren, Frans H., Grootendorst, Rob e.a. (eds.) Proceedings of the Fourth International Conference of the International Society for the Study of Argumentation. Amsterdam: Sic Sat, pp. 455-460. (Also published as 
(1999) Visual Rhetoric - From Elocutio to Inventio. Working. University of Bergen: Department of Media Studies, Papers 34/99)

Larsen, Peter (1980) Reklame og retorik. In Fausing, Bent \& Larsen, Peter (eds.) Visuel kommunikation. København: Medusa, pp. 42-57.

Larsen, Peter (1994) De levende billeders retorik. Oversigt over en problematik. In Meyer, Siri \& Ågotnes Knut (eds.) Den retoriske vending? Universitet i Bergen: Senter for Europeiske Kulturstudier, pp. 70-91

Larsen, Peter (1995) TV-analyse for mediestuderende. Tre kapitler om betydning og fortalleanalyse. Universitet i Bergen: Institutt for medievitenskap, (Arbejdspapirer).

Larsen, Peter (1997) Fra figur til figurering - om film \& retorik. In Rhetorica Scandinavica 1, pp. 44-53. Syvmil Kommunikation.

Lippe, Berit von der (1995) Reklame i grenselaus knoppskyting. Kritiske analysar av medietekster. Gjøvik: Det Norske Samlaget.

Matz, Tom (ed.) (1998) Uffes lille blå. Citater og tanker af Venstres formand og Danmarks kommende statsminister Uffe Ellemann-Jensen. Viborg: Venstres Landsorganisation.

Nordström, Gert Z (1986) Påverkan genom bilder. Stockholm: Styrelsen for Psykologisk Försvar.

Nordström, Gert Z (ed.) (1996) Rum. Relation. Retorik - Ett projekt om bildteori och bildanalys $i$ det postmoderna samhället. Stockholm: Carlssons.

Paine, Robert (1981) The Political Uses of Metaphor and Metonym: An Exploratory Statement. In Paine, Robert (ed.) Politically Speaking: Cross-Cultural Studies of Rhetoric. Philadelphia: Institute for the Study of Human Issues.

Perelman, Chaim \& Olbrechts-Tyteca, L. (1971 [1969]) The New Rhetoric. A Treatise on Argumentation. London: University of Notre Dame Press ( $1^{\text {st }}$ paperback ed.).

Petty, Richard E. \& Cacioppo John T. (1981) Issue Involvement as a Moderator of the Effects on Attitude of Advertising Content and Context. In Advances in Consumer Research, 8. Urbana: Association for Consumer Research, pp. 20-24.

Petty, Richard E. \& Cacioppo John T. (1986) Communication and Persuasion. Central and Peripheral Routes to Attitude Change. New York: Springer-Verlag.

Petty, Richard E. \& Cacioppo John T. (1996 [1981]) Attitudes and Persuasion Classic and Contemporary Approaches. Boulder, Colorado: WestviewPress.

Saussure, Ferdinand de (1959 [1916]) Course in General Linguistics. New York: Philosophical Library (Ed.: Bally, C. \& Sechehaye, A., Trans.: Baskin, Wade).

Skretting, Kathrine (1995) Reklamefilm. Norsk reklame i levende billeder 1920-1990. Oslo: Universitetsforlaget.

Toulmin, Stephen (1994 ]1958]) The Uses of Argument. Cambridge: Cambridge University Press.

Toulmin, Stephen, Richard Rieke \& Allan Jannik (1984) An Introduction to Reasoning, New York: Macmillan Publishing, (2 $2^{\text {nd }}$ ed.).

Vickers, Brian (1997 [1988]) In Defence of Rhetoric. Oxford: Clarendon Paperbacks.

Walker, John A. \& Chaplin, Sarah (1997) Visual Culture: An Introduction. Manchester \& New York: Manchester University Press. 